\title{
Model of Online-Teaching Platform Use in Higher Education Business School
}

\author{
Meika Kurnia Puji Rahayu \\ \{meika_kurnia@umy.ac.id\} \\ Faculty of Economics and Business, Universitas Muhammadiyah Yogyakarta, Indonesia
}

\begin{abstract}
This study aims to depict a model of Information and Communication Technology use, especially an online teaching-learning platform known as eLearning, in a Higher Education Business Schools. The investigation focuses on two aspects, how and why HEBS lecturers use eLearning in teaching. Sixty five lecturers participated in the study. Data was collected through interviews and physical artefact study by accessing eLearning accounts of each lecturer. Using a qualitative descriptive analysis approach, the results shows that although all participants had accessed eLearning, but the utilization was not as expected. Mostly the lecturers used eLearning just for uploaded their course material. Their main reason for using eLearning platform is the pedagogical reason, it is using online teaching platform to improve learning process. However, this reason is inconsistent with the fact that not all lecturers use eLearning actively and optimally to improve the quality of lectures. This research contributes to the development of Faculty policies, particularly in the improvement of the quality eLearning use which can improve teaching and learning.
\end{abstract}

Keywords: Online Teaching Platform, Business Schools, Use of Technology

\section{Introduction}

There is an increased scrutiny of Information and Communication Technology (ICT) and its use for analysing the Higher Education Business Schools (HEBSs) improvement (Alavi and Gallupe, 2003; Arbaugh et al., 2009, 2016; Arbaugh and Hwang, 2013). Scholars argue that ICT use is a prominent reason for changes in HEBSs due to the demand of an ICT savvy business community and students, (Lepeley and Albornoz, 2012; Seethamraju, 2012; Zeeshan et al., 2011). It is important that HEBSs need to understand the changes in contemporary businesses which have effects on business growth and development as well as business education itself (Escudero, 2011; Hawawini, 2005; Kao and Mao, 2011). They are required to be close and learn from businesses for their success. Therefore, as businesses embrace ICT to enhance their competitiveness, HEBS should pay attention on the integration of ICT into daily activities, including teaching and learning.

ICTs enable HEBS institutions to provide simple yet faster managerial processes and routine activities (Bates and Sangrà, 2011; Hudson, 2010). For example, online and electronic based activities for student admission and academic report. ICTs, such as e-mail, video and teleconferencing technologies improve communication among lecturers, staff and students (Chase and Clegg, 2013; Gan and Balakrishnan, 2014; Lauricella and Kay, 2013). The use of ICTs in HEBS institutions nowadays have embraced the development of online platforms, such as eLearning to improve teaching and learning. The online platforms complete or supplement the conventional mode of teaching (face-to-face classes). 
Using online teaching platforms, lecturers are able to provide learning environments in which students have more opportunities to independently obtain and share knowledge (Nawaz and Khan, 2012; Noor-Ul-Amin, 2013; Renes and Strange, 2011; Rienties and Townsend, 2012). There is also improvements on student skills and competencies, such as communication, information handling, and problem solving when lecturers use an online teaching platform (Alavi and Gallupe, 2003; Lynn and Alexopoulos, 2011).

Since there are promising benefits from the use of ICT in teaching and learning, hence, it is necessary to pay attention on how lecturers use it and why they want to do it. The research gap identified, however, is a lack of studies examining how and why lecturers in HEBSs use ICT in teaching and learning. Prior studies mostly focused on three main themes (Arbaugh et al., 2009). The themes are narrative accounts of instructor experiences and best practice; empirical studies of student perceptions, attitudes, and behaviours regarding the delivery of online courses; and comparison studies of courses offered in online and classroom-based formats. Thus, a study investigate the use of ICT in teaching and learning in HEBSs, focusing on how and why lecturers use it, is valuable.

From a little literature focusing on how and why HEBSs lecturers use ICT in teaching and learning, there are unsatisfactory findings. The use of ICT in teaching and learning in HEBS is not as expected. Prior studies revealed that lecturers' ability in using ICT is still problematic (Blin and Munro, 2008; Kirkup and Kirkwood, 2005; Selwyn, 2007; Watty et al., 2016). In addition, HEBSs have developed ICT-integrated learning system, however the teaching approach is still teacher centred, showing that lecturers seem do not understand the benefits of ICT use. Moreover, instead of using ICT for learning purposes, lecturers use ICT only for storing data and subject matter or only for word processing or spreadsheet assignments (Fry and Love, 2011). Even there are evidence that the use of ICT in teaching and learning in HEBS, such as online-based classrooms, has no effect on the improvement of learning process (Hu and Hui, 2012; Means et al., 2009; Redmann and Kotrlik, 2004; Suzmann et al., 2006).

Filling the research gap, the study reported in this paper aims to investigate how and why HEBSs lecturers use ICT, especially an online teaching platform. The contribution of the study is to provide a model of ICT use in HEBSs.

\section{Literature Review}

\subsection{ICT}

There are various definitions exist around the term ICT. Scholars and practitioners have diverse understandings of its scope since the term has been used widely in a variety of contexts, including government, business, industry and education (Lloyd, 2005; Zuppo, 2012). In educational context, in particular, scholars often use others terms, such as Information Technology (IT), educational technology, and instructional technology to substitute the term ICT (Ashleigh, 2005; Hlynka and Jacobsen, 2009; Surjono and Gafur, 2010).

Berce et al. (2008) define ICT as an assortment of tools, including hardware, software, and communications facilities (such as local area networks or LAN, wide area networks or WAN, the Internet, and bandwidth). Inherent in this term is conventional technologies (such as radio, television and telephone technology) and sophisticated computer-based technologies (Reddi, 2004). Correspondingly, Oliver and Clayes (2014) suggest that ICT is technologies that provide access to information through telecommunications, for example, the Internet, web-based devices, wireless networks, and cell phones. Thus, include in the definition of ICT 
in teaching is eLearning, an online teaching platform or Internet-based teaching media through which lecturers and students are able to conduct online interactions.

\subsection{Technology Acceptance Model}

To understand how lecturers use ICT in teaching and learning in HEBSs, literature shows well-established theoretical models. Kim and Malhotra (2005) identified four most frequent applied models to study ICT use. These include the Theory of Reasoned Action (TRA) (Fishbein and Ajzen, 1975), the Theory of Planned Behaviour (TPB) (Ajzen, 1985), the Technology Acceptance Model (TAM) (Davis, 1985, 1989), and Innovation Diffusion Theory (IDT) (Rogers 1983).

Amongst the four models, TAM has been recognised as the most well-known theory and a valid model for explaining individuals' use and acceptance of ICT (Marangunić and Granić, 2015; ŠUmak et al., 2011; Wu et al., 2011). It has been applied in research in multiple fields, including higher education setting, for example Adewole-Odeshi (2014), Al-Adwan et al. (2013), Edmunds et al. (2012), Fathema et al. (2015), Lane and Stagg (2014), and Shahrabi et al. (2013).

TAM is a simple model since it only has two main determinants, perceived ease of use and perceived usefulness. The ICT use is defined as the degree of current usage of technology, measured using a short questionnaire (Davis, 1989; Venkatesh and Bala, 2008). However, for some reasons, the simplicity of TAM is not its strength, it is also its drawback. The model is a subjective measure on which to base findings of intention and usability. The intention may not represent and reflect the actual use (Lin and Wang, 2005; Turner et al., 2010).

Addressing the shortcomings of TAM, a combined theoretical framework used in this study, enabling the researcher investigated ICT use more than as the general view of reported in the literature (frequency of ICT use) as proposed by TAM. The investigation covered the frequency of use, what, why, and how ICT is used (Weston, 2005).

\subsection{Reason for Using ICT in Teaching}

According to Bates and Poole (2003) and Hawkridge (1990), there are six reasons that lecturers use ICT in teaching.

1. Pedagogy. This reason focuses on using ICT to improve teaching and learning. Included in this category is lecturers' ability to enhance student engagement in teaching and learning activities as well as student performance when they integrate ICT into the activities.

2. Catalyst. This reason focuses on the ability of ICT to act as a catalyst for educational institutions to change. Within this category, ICT facilitates lecturers and students to change as well as institutions to realise their institutional planning and vision.

3. Accessibility. This third reason is about the ability of ICT to enable lecturers or schools to provide wider access to learning opportunities and flexibilities for students. It also includes increasing communication access between students and lecturers, unbound by time, locations, and demography.

4. Cost-effectiveness. Within this reason, lecturers use ICT in teaching because it leads to cost savings in delivering the teaching, for example by possible savings on printing costs and the cost of employing academic staff. 
5. Preparative. This reason focuses on using ICT to equip students with required skills for their future career.

6. Accommodating to the learning style of a new generation of students. This reason is about the use of ICT to meet the needs of today's learners, those who have grown up in a digital world.

\section{Research Method}

The study was exploratory nature. Thus, qualitative research approach was used (Braun \& Clarke 2013). There was no attempt to find a single answer for understanding ICT use in HEBS. There were no hypotheses tested. The approach enabled the researcher conducting indepth investigations in natural settings to discover the reason to use ICT in HEBS (Creswell 2009).

The term ICT refers to an online teaching platform hereinafter referred to as eLearning. Research subject was HEBS lecturers at a private university in Indonesia. Sixty five lecturers were involved as research participants. To identify the way (how) lecturers used ICT, the researcher conducted physical artefacts technique (Yin 2009), that was by accessing the eLearning account of each participant. To investigate the reason (why) lecturers used ICT in teaching, individual interviews were conducted to collect primary data. The researcher used three steps of qualitative data analysis: data reduction, data display, and conclusion drawing (Miles et al., 2014).

\section{Results and Discussions}

There were three groups of participants based on the study programs namely Management, Accounting and Development Economics. As shown in Table 4.1 number of participants from Management and Accounting study program were nearly same, 38\% and 39\%. Number of participants from Development Economics study program was 15 persons or equal $23 \%$.

\begin{tabular}{|c|c|c|}
\hline \multicolumn{2}{|c}{ Table 1. Group of Participants } \\
\hline Study Program & $\begin{array}{c}\text { Number of } \\
\text { respondents }\end{array}$ & $\%$ participation \\
\hline Management & 24 & $38 \%$ \\
\hline Accounting & 25 & $39 \%$ \\
\hline $\begin{array}{c}\text { Development } \\
\text { Economics }\end{array}$ & 15 & $23 \%$ \\
\hline Total & 65 & $100 \%$ \\
\hline
\end{tabular}

The results show various findings. The basic benefit of eLearning is to enable lecturers uploading their course material online. However, not all participants utilised that facility. Table 2 summaries the description of how lecturers used ICT (eLearning) in teaching.

Table 2. E-Learning Use for uploading material, online assignment and online quizzes/exam

\begin{tabular}{|c|c|c|c|}
\hline $\begin{array}{c}\text { Study } \\
\text { Program }\end{array}$ & $\begin{array}{c}\text { Use eLearning for uploading } \\
\text { course material (\%) }\end{array}$ & $\begin{array}{c}\text { Use eLearning for } \\
\text { online assignment (\%) }\end{array}$ & $\begin{array}{c}\text { Use eLearning for online quizzes/exam } \\
(\%)\end{array}$ \\
\hline Management & 96 & 46 & 42 \\
\hline Accounting & 64 & 56 & 40 \\
\hline
\end{tabular}




\begin{tabular}{|c|c|c|c|}
\hline $\begin{array}{c}\text { Development } \\
\text { Economics }\end{array}$ & 47 & 40 & 40 \\
\hline
\end{tabular}

Lecturers from Management study program mostly used eLearning for delivering course material (96\%). However, only about forty percent of participants use eLearning for online assignment or quizzes. The use of eLearning to store lecture material by Accounting lecturers is fairly good, sixty four percent. But there are still a few who used it to give online exams $(40 \%)$. A concern is the lecturers from Development Economics study program. Less than fifty percent of participants who actively used eLearning for uploading their course material, delivering online assignment and online exams. The results show that the number of participants who used eLearning to conduct more advanced-usage of eLearning, such as online discussions and grading is little.

Table 3. The Advanced-Usage of E-Learning (for online discussions and grading)

\begin{tabular}{|c|c|c|}
\hline Study Program & $\begin{array}{c}\text { Use } \\
\text { eLearning } \\
\text { for online } \\
\text { discussions } \\
(\%)\end{array}$ & $\begin{array}{c}\text { Use } \\
\text { eLearning } \\
\text { for online } \\
\text { grading } \\
(\%)\end{array}$ \\
\hline Management & 42 & 42 \\
\hline Accounting & 40 & 20 \\
\hline Development Economics & 40 & 40 \\
\hline
\end{tabular}

Table 3 displays that participants from all study programs who used eLearning for discussion and grading is less than fifty percent. Sequentially, as shown in Table 3, Management 42\%, Accounting 40\% Development Economy 40\%. There are also small number of lecturers who conducted online grading.

Sixty percent of participants stated that the main reason for using e-learning was a pedagogy. This reason indicates that the lecturers used eLearning based on their beliefs that eLearning enabled them to improve teaching. The participants revealed that using eLearning eased them to provide various teaching media, including videos, pictures, and links to relevant websites. The participants also stated that using eLearning has enabled them to engage students through online activities, such as online discussion. The second reason for using eLearning in teaching found in this study is catalyst, meaning that eLearning influence lecturers to change. Lecturers moved from teacher-centred learning to student-centred learning. The third reason for using eLearning found in this study was cost-effectiveness. Lecturers said that using eLearning was cost saving. Lecturers do not need to print lecture material or assignments or exam questions because they just uploaded the course material through their respective eLearning accounts. Likewise students, they do not need to photocopy or print lecture material because they can simply download the files.

\section{Conclusion}

While advanced ICT has proven to have great potential to enhance teaching and learning in HEBSs, literature indicates an inconsistency in ICT use. The literature shows a lack of understanding about how lecturers use ICT. This study found that ICT use in teaching and learning in HEBS in particular has not reached the expectation. Although there is an increase of lecturers awareness to use an online teaching platform, such as eLearning, the lecturers are 
still unaware its benefits. They have not used eLearning properly. Majority of participants used the online platform only as a tool for storing the course material. In addition, the number of lecturers who used the platform (eLearning) for more interactive activities, such as online discussion or online quizzes is still few.

The findings explained above is not in line with the reasons for using eLearning. As discussed before, the strongest reason is the pedagogical reason, indicating that lecturers use eLearning for enriching their teaching media or method. However, the results show a small number of lecturers used eLearning for more advanced use of eLearning, such as online assignment, online quizzes/exam, online discussions, and online grading. In addition to the pedagogical reason, lecturers use e-learning is catalyst reason, while the last is cost effectiveness reason. There was no data can be used to explain these two reasons. Therefore, future research need to explore more information about how and why ICT is used in teaching and learning in HEBSs. Recommendations for practice addressed to HEBS management or faculty or university to develop strategies, such as policies for better usage of eLearning in teaching and learning.

\section{References}

Adewole-Odeshi, E. (2014), "Attitude of students towards e-learning in South-West Nigerian universities: An application of Technology Acceptance Model", Library Philosophy and Practice (ejournal). 1035

Al-Adwan, A., Al-Adwan, A. and Smedley, J. (2013), "Exploring students' acceptance of e-learning using Technology Acceptance Model in Jordanian universities", International Journal of Education and Development using ICT, 9(2).

Ajzen, I. (1985), "From intentions to actions: A theory of planned behavior", Action Control, Springer, pp. 11-39.

Alavi, M. and Gallupe, R.B. (2003), "Using Information Technology in Learning: Case Studies in Business and Management Education Programs", Academy of Management Learning \& Education, Vol. 2 No. 2, pp. 139-153.

Arbaugh, J.B., Fornaciari, C.J. and Hwang, A. (2016), "Identifying Research Topic Development in Business and Management Education Research Using Legitimation Code Theory", Journal of Management Education, Vol. 40 No. 6, pp. 654-691.

Arbaugh, J.B., Godfrey, M.R., Johnson, M., Pollack, B.L., Niendorf, B. and Wresch, W. (2009), "Research in online and blended learning in the business disciplines: Key findings and possible future directions", The Internet and Higher Education, Elsevier Inc, NEW YORK, Vol. 12 No. 2, pp. 71-87.

Arbaugh, J.B. and Hwang, A. (2013), "Uses of Multivariate Analytical Techniques in Online and Blended Business Education: An Assessment of Current Practice and Recommendations for Future Research", Journal of Management Education, Vol. 37 No. 2, pp. 229-260.

Ashleigh, D.A. (2005), A Study of Successful Implementation and Management of Educational Technology in Three New South Wales Primary Schools, Australian Catholic University.

Bates, T. and Sangrà, A. (2011), Managing Technology in Higher Education: Strategies for Transforming Teaching and Learning, Jossey-Bass, San Francisco.

Blin, F. and Munro, M. (2008), "Why hasn't technology disrupted academics' teaching practices? Understanding resistance to change through the lens of activity theory", Computers \& Education, Elsevier, Vol. 50 No. 2, pp. 475-490.

Chase, N.M. and Clegg, B. (2013), "Effects of email utilization on higher education professionals", User Perception and Influencing Factors of Technology in Everyday Life, IGI Global, pp. 233-247.

Davis, F.D. (1985), "A technology acceptance model for empirically testing new end-user information systems: Theory and results", Massachusetts Institute of Technology.

Davis, F.D. (1989), "Perceived usefulness, perceived ease of use, and user acceptance of information 
technology", MIS Quarterly, JSTOR, pp. 319-340.

Escudero, M. (2011), "PRME and four theses on 20 the future of management education", Business Schools and Their Contribution to Society, SAGE, p. 201.

Fishbein, M. and Ajzen, I. (1975), Belief, Attitude, Intention and Behavior: An Introduction to Theory and Research, Addison-Wesley Publishing Company, Canada.

Fry, N. and Love, N. (2011), "Business lecturers' perceptions and interactions with the virtual learning environment", International Journal of Management Education, Vol. 9 No. 4, pp. 51-56.

Gan, C.L. and Balakrishnan, V. (2014), "Determinants of mobile wireless technology for promoting interactivity in lecture sessions: An empirical analysis", Journal of Computing in Higher Education, Springer, Vol. 26 No. 2, pp. 159-181.

Hawawini, G. (2005), "The future of business schools", Journal of Management Development, Vol. 24 No. 9, pp. 770-782.

Hlynka, D. and Jacobsen, M. (2009), "What is educational technology, anyway? A commentary on the new AECT definition of the field", Canadian Journal of Learning and Technology/La Revue Canadienne de l'apprentissage et de La Technologie, Vol. 35 No. 2.

$\mathrm{Hu}$, P.J.-H. and Hui, W. (2012), "Examining the role of learning engagement in technology-mediated learning and its effects on learning effectiveness and satisfaction”, Decision Support Systems, Vol. 53 No. 4, pp. 782-792.

Hudson, K. (2010), Working Together: The Role of Collaborations in Promoting the Use of Academic Technologies in Higher Education, ProQuest Dissertations and Theses, University of Massachusetts Amherst, Ann Arbor, available at: http://search.proquest.com/docview/816503205?accountid=10424.

Kao, D. and Mao, T. (2011), "A framework for aligning business education with dynamic changes in global competition", Journal of Higher Education Theory and Practice, Vol. 11 No. 1, pp. 9-21.

Kirkup, G. and Kirkwood, A. (2005), "Information and communications technologies (ICT) in higher education teaching - a tale of gradualism rather than revolution", Learning, Media and Technology, Taylor \& Francis, Vol. 30 No. 2, pp. 185-199.

Lauricella, S. and Kay, R. (2013), "Exploring the use of text and instant messaging in higher education classrooms.", Research in Learning Technology, Vol. 21.

Lepeley, M.-T. and Albornoz, C. (2012), "Business Education in Chile: Advancing to the 21 st Century People Centered-Innovation Based Entrepreneurial 'Mega Trend"'.

Lin, H.-H. and Wang, Y.-S. (2005), "Predicting consumer intention to use mobile commerce in Taiwan", Mobile Business, 2005. ICMB 2005. International Conference On, IEEE, pp. 406-412.

Lloyd, M.M. (2005), "Towards a definition of the integration of ICT in the classroom", Australian Association for Research in Education.

Lynn, T.G. and Alexopoulos, A. (2011), "Technology in the Daily Lives and Educational Experiences of Business Students", Ssrn, available at:https://doi.org/10.2139/ssrn.1973030.

Marangunić, N. and Granić, A. (2015), “Technology acceptance model: a literature review from 1986 to 2013", Universal Access in the Information Society, Springer Berlin Heidelberg, Berlin/Heidelberg, Vol. 14 No. 1, pp. 81-95.

Means, B., Toyama, Y., Murphy, R., Bakia, M. and Jones, K. (2009), "Evaluation of evidence-based practices in online learning: A meta-analysis and review of online learning studies", Centre for Learning Technology.

Miles, M.B., Huberman, A.M. and Saldaña, J. (2014), Qualitative Data Analysis: A Methods Sourcebook, SAGE Publications, Inc, Thousand Oaks, Califorinia.

Nawaz, A. and Khan, M.Z. (2012), "Issues of technical support for e-learning systems in Higher Education Institutions", International Journal of Modern Education and Computer Science (IJMECS), Citeseer, Vol. 4 No. 2, p. 38.

Noor-Ul-Amin, S. (2013), "An effective use of ICT for education and learning by drawing on worldwide knowledge, research, and experience: ICT as a change agent for education", Scholarly Journal of Education, Vol. 2 No. 4, pp. 38-45.

Reddi, U.V. (2004), "Role of ICTs in education and development: potential, pitfalls and challenges", Acedido Em Junho, Vol. 30, p. 2014. 
Redmann, D.H. and Kotrlik, J.W. (2004), "Technology Integration into the Teaching-Learning Process by Business Education Teachers", Delta Pi Epsilon Journal, Vol. 46 No. 2, pp. 76-91.

Renes, S.L. and Strange, A.T. (2011), "Using Technology to Enhance Higher Education", Innovative Higher Education, Springer Netherlands, Dordrecht, Vol. 36 No. 3, pp. 203-213.

Rienties, B. and Townsend, D. (2012), "Integrating ICT in business education: using TPACK to reflect on two course redesigns", Learning at the Crossroads of Theory and Practice, Springer, pp. 141156.

Seethamraju, R. (2012), “Business process management: a missing link in business education”, Business Process Management Journal, Emerald, Bradford, Vol. 18 No. 3, pp. 532-547.

Selwyn, N. (2007), "The use of computer technology in university teaching and learning: a critical perspective", Journal of Computer Assisted Learning, Wiley Online Library, Vol. 23 No. 2, pp. 83-94.

ŠUmak, B., HeričKo, M. and PušNik, M. (2011), “A meta-analysis of e-learning technology acceptance: The role of user types and e-learning technology types", Computers in Human Behavior, Elsevier, Vol. 27 No. 6, pp. 2067-2077.

Surjono, H.D. and Gafur, A. (2010), "Potensi pemanfaatan ICT untuk peningkatan mutu pembelajaran SMA di kota Yogyakarta", Cakrawala Pendidikan, Vol. 2 No. 2.

Suzmann, T., Kraiger, K., Stewart, D. and Wisher, R. (2006), "The comparative effectiveness of webbased and classroom instruction: A meta-analysis", Personnel Psychology, Vol. 59 No. 3, pp. 623-664.

Turner, M., Kitchenham, B., Brereton, P., Charters, S. and Budgen, D. (2010), "Does the technology acceptance model predict actual use? A systematic literature review", Information and Software Technology, Elsevier B.V, AMSTERDAM, Vol. 52 No. 5, pp. 463-479.

Venkatesh, V. and Bala, H. (2008), "Technology acceptance model 3 and a research agenda on interventions", Decision Sciences, Wiley Online Library, Vol. 39 No. 2, pp. 273-315.

Watty, K., McKay, J. and Ngo, L. (2016), "Innovators or inhibitors? Accounting faculty resistance to new educational technologies in higher education", Journal of Accounting Education, Elsevier Ltd, Vol. 36, pp. 1-15.

Weston, T.J. (2005), "Why faculty did — and did not—integrate instructional software in their undergraduate classrooms", Innovative Higher Education, Springer, Vol. 30 No. 2, pp. 99-115.

Wu, K., Zhao, Y., Zhu, Q., Tan, X. and Zheng, H. (2011), "A meta-analysis of the impact of trust on technology acceptance model: Investigation of moderating influence of subject and context type", International Journal of Information Management, Elsevier, Vol. 31 No. 6, pp. 572-581.

Zeeshan, A., Hashmi, M.A. and Bhatti, N. (2011), "Impact of Technology on Business Schools: Perceptions of Faculty \& Management.", Journal of Research \& Reflections in Education (JRRE), Vol. 5 No. 2, pp. 128-145.

Zuppo, C.M. (2012), "Defining ICT in a Boundaryless World: The Development of a Working Hierarchy", International Journal of Managing Information Technology, Academy \& Industry Research Collaboration Center (AIRCC), Vol. 4 No. 3, pp. 13-22. 
